\title{
Economic feasibility of developing large scale solar photovoltaic power plants in Spain
}

\author{
Javier Menéndez ${ }^{1, *}$ and Jorge Loredo ${ }^{2}$ \\ ${ }^{1}$ HUNASER ENERGÍA, 33005 Oviedo, Spain \\ ${ }^{2}$ UNIVERSITY OF OVIEDO, Mining Exploitation Department, 33004 Oviedo, Spain
}

\begin{abstract}
In 2017, electricity generation from renewable sources contributed more than one quarter $(30.7 \%)$ to total EU-28 gross electricity consumption. Wind power is for the first time the most important source, followed closely by hydro power. The growth in electricity from photovoltaic energy has been dramatic, rising from just 3.8 TWh in 2007, reaching a level of $119.5 \mathrm{TWh}$ in 2017 . Over this period, the contribution of photovoltaic energy to all electricity generated in the EU-28 from renewable energy sources increased from $0.7 \%$ to $12.3 \%$. During this period the investment cost of a photovoltaic power plant has decreased considerably. Fundamentally, the cost of solar panels and inverters has decreased by more than $50 \%$. The solar photovoltaic energy potential depends on two parameters: global solar irradiation and photovoltaic panel efficiency. The average solar irradiation in Spain is $1,600 \mathrm{kWh} \mathrm{m}^{-2}$. This paper analyzes the economic feasibility of developing large scale solar photovoltaic power plants in Spain. Equivalent hours between $800-1,800 \mathrm{~h}_{\text {year }}^{-1}$ and output power between 100-400 MW have been considered. The profitability analysis has been carried out considering different prices of the electricity produced in the daily market (50-60€ $\mathrm{MWh}^{-1}$ ). Net Present Value (NPV) and Internal Rate of Return (IRR) were estimated for all scenarios analyzed. A solar PV power plant with $400 \mathrm{MW}$ of power and 1,800 h year ${ }^{-1}$, reaches a NPV of $196 \mathrm{M} €$ and the IRR is $11.01 \%$.
\end{abstract}

\section{Introduction}

The use of renewable energies in the generation of electric power has increased considerably in recent years. Gross electricity generation in Organisation for Economic Co-operation and Development (OECD) from renewable energy sources (excluding generation from pumped storage plants) reached 2,588.3 TWh in 2016, a $3.8 \%$ increase from the 2015 . This represents $23.8 \%$ of total OECD electricity production in 2016 (Fig. 1), which is the largest share of renewables in gross electricity production for any year in the renewables time series beginning from 1990 [1].

\section{Renewable shares in OECD electricity production in 2016}

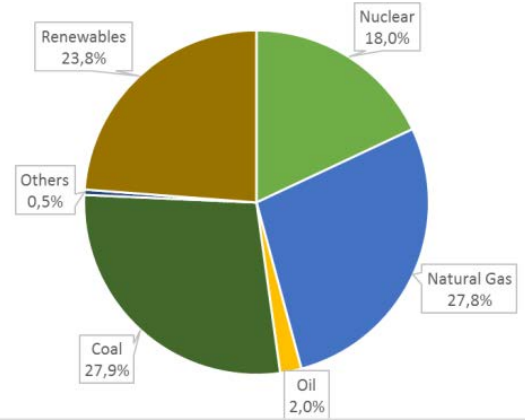

Fig. 1. Renewable shares in OECD electricity production in $2016[1]$.
The increase in electricity production from renewables was mainly caused by wind and solar photovoltaic (PV). Solar PV increased by 35.0 TWh, again mainly driven by the US, which had increased electricity production from solar PV by $18.0 \mathrm{TWh}$, followed by Japan (8.0 TWh), UK (2.7 TWh) and Chile (1.3 TWh) [1].

Solar energy is currently the lowest cost power generation source in many regions of the world - and its cost continues to decrease rapidly. Solar has the potential to play a major role in the European Union meeting its $32 \%$ renewables target by 2030 . Bloomberg NEF, in its New Energy Outlook 2018, anticipates that renewables will cover $87 \%$ of Europe's electricity generation by 2050 in Europe, in which 1.4 TW of solar is installed and contributes to $36 \%$ of total power generation.

The increase of renewable energy sources requires flexible energy storage systems. Pumped-storage hydropower (PSH) is the most mature and efficient technology that currently exists. Other systems, such as Compressed Air Energy Storage (CAES) plants, can also be used. Underground pumped storage power plants can be an alternative using underground space, such as closed mines. [2-6].

Fig. 2 shows the renewable energy sources in electricity in EU'28 in 2017. The share of renewable energy sources has increased from $16.97 \%$ to $30.75 \%$ in

* Corresponding author: javiermenendezr@gmail.com 
the period 2008-2017. It highlights, Austria, Sweden, Denmark, Latvia and Portugal, with a share in the electric mix higher than $50 \%$ in 2017. The share of renewable energies in electricity in Spain was $36.34 \%$.

EU 2017: Renewable energy sources in electricity (\%)

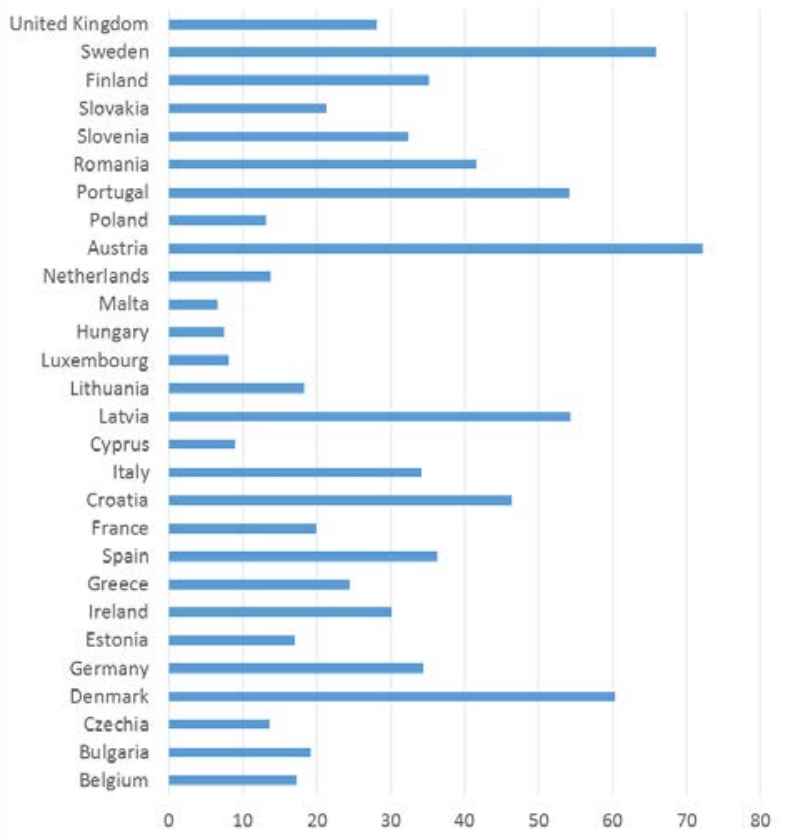

Fig. 2. Renewable energy sources in electricity in EU'28 (2017).

This paper analyzes the economic feasibility of developing large scale solar PV projects in Spain. Different output power (100-400 MW) and equivalent hours per year, depending on the situation of the solar PV power plant $\left(800-1,800 \mathrm{~h}\right.$ year $\left.{ }^{-1}\right)$ have been considered in this study. A profitability analysis has been carried out for different prices of the electricity produced in the daily market $\left(50-60 € \mathrm{MWh}^{-1}\right)$. Net Present Value (NPV) and Internal Rate of Return (IRR) were obtained in all scenarios.

\section{Materials and methods}

\subsection{Solar energy in Spain}

Spain offers optimal conditions for the installation of solar PV power plants [7]. Fig. 3 shows a detailed map of the annual accumulated solar irradiation level $(\mathrm{kWh}$ $\mathrm{m}^{-2}$ ) for EU considering optimally-inclined PV modules $[8,9]$. In Spain, the average values vary from 1,000 hours year ${ }^{-1}$ (equivalent hours) on the northern and 1,700 hours year ${ }^{-1}$ (equivalent hours) on the southaestern zone [10]. The national average is $1,600 \mathrm{kWh} \mathrm{m}^{-2}$ [11].

Electricity generation in Spain from renewable energy spurces reached $101,6 \mathrm{TWh}$ in 2018 , a $40.1 \%$ of total electricity production in 2018. The total installed power in Spain reached $98.5 \mathrm{GW}$ in 2018. The total power of solar PV accumulated in 2018 reached 4,436 MW (4.5\% of the total installed power).

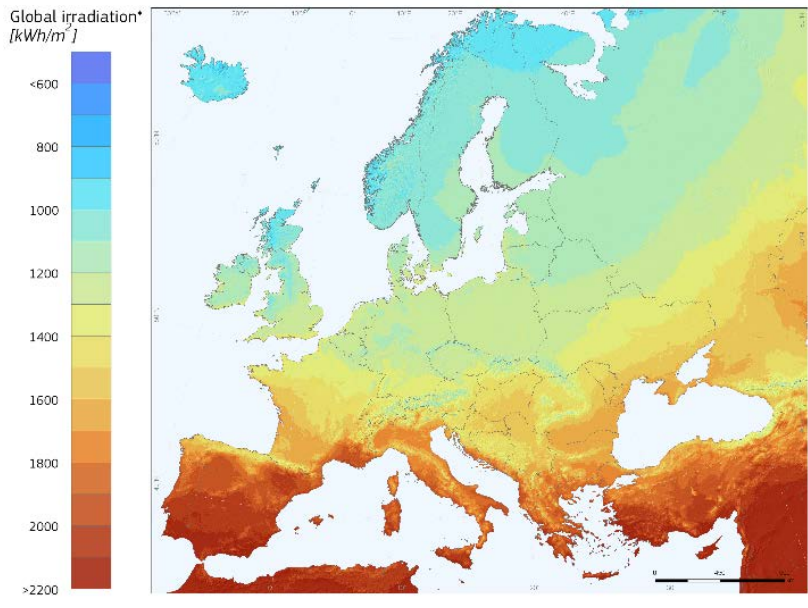

Fig. 3. Map of the annual accumulated solar irradiation level for EU. Optimally-inclined PV modules [8].

\subsection{Solar energy calculator}

The solar energy potential depends on two parameters: solar irradiation and PV panel efficiency. The power output of the PV is given by Eq. (1).

$$
P_{P V}=\sum Y_{P V} D_{f}\left[1+\alpha\left(T_{o}-T_{C, S T C}\right)\right] P_{V N}
$$

where:

$\mathrm{P}_{\mathrm{PV}}$ : Annual PV solar power output

$\mathrm{Y}_{\mathrm{PV}}$ : PV panel power output

$\mathrm{D}_{\mathrm{f}}$ : Degradation factor $\left(0.5 \%\right.$ year $\left.^{-1}\right)$

$\alpha$ : Temperature loss coefficient

$\mathrm{T}_{\mathrm{o}}$ : Operating temperature

$\mathrm{T}_{\mathrm{C}, \mathrm{STC}}$ : Temperature at Standard Test Conditions $\left(25^{\circ} \mathrm{C}\right)$ $\mathrm{P}_{\mathrm{Vn}}$ : Number of PV panels

The panel power output, $\mathrm{Y}_{\mathrm{PV}}(\mathrm{kW})$ is given by Eq. (2). Finally, the total power produced by $\mathrm{PV}$ power $\left(\mathrm{P}_{\mathrm{PV}}\right)$ plant is given by Eq. (3)

$$
\begin{gathered}
Y_{P V}=R_{G H I} A d_{m} \eta_{P V} \\
P_{S P}=P_{P V} L_{S P}
\end{gathered}
$$

where:

$R_{G H I}$ : Monthly average solar irradiation $\left(\mathrm{kWh} \mathrm{m}^{-2}\right)$

$A$ : Area of PV panel $\left(\mathrm{m}^{2}\right)$

$d_{m}:$ Number a days per month

$\eta_{V}$ : PV conversion efficiency

$P_{S P}$ : Power output of solar plant $(\mathrm{kWh})$

$L_{S P}:$ Solar plant losses

Table 1 shows the system losses in a solar PV power plant. Considering a useful life of 25 years, the PV module degradation reaches a value of $12.5 \%$ of the total energy produced in year 25. The solar PV modules must be periodically cleaned to avoid losses in the generation of electricity. The typical power of a PV module (peak power) is $315 \mathrm{~W}$, with a dimensions of $1,956 \times 992 \mathrm{~mm}$. 
Table 1. Solar PV power plant. System losses

\begin{tabular}{c|c}
\hline \multicolumn{2}{c}{ Solar PV plant system losses } \\
\hline PV module degradation (D) & $0.5 \%$ year $^{-1}$ \\
\hline $\begin{array}{c}\text { PV module performance due to } \\
\text { temperature }(\alpha)\end{array}$ & $0.41 \%{ }^{\circ} \mathrm{C}^{-1}$ \\
\hline Inverter efficiency loss & $2.5-5 \%$ \\
\hline Loss due to soiling of module surface & $0.5-10 \%$ \\
\hline AC wiring & $1-3 \%$ \\
\hline DC wiring & $1-2.5 \%$ \\
\hline Connectors & $1-2.5 \%$ \\
\hline System availability & $1-3 \%$ \\
\hline
\end{tabular}

\subsection{Economic evaluation: NPV and IRR}

The economic evaluation consists in the analysis of the profits obtained from the solar PV power plant invested by a promoter on the basis of NPV $(€)$ and IRR (\%). NPV is calculated in the way of subtracting the investment cost (current) from the future cash flow obtained during the operation phase. IRR is used to analyze what discount rate would cause the NPV of a project to be ' 0 ' $€$ and then comparing the value with expected rate of return. NPV and IRR are given by Eq. (4) and Eq. (5) as follows:

$$
\begin{gathered}
N P V=\sum_{t=0}^{n} \frac{B_{t}}{(1+r)^{t}}=\sum_{t=0}^{n} \frac{C F_{t}}{(1+r)^{t}} \\
I R R=\sum_{t=0}^{n} \frac{B_{t}}{(1+r)^{t}}=\sum_{t=0}^{n} \frac{C F_{t}}{(1+r)^{t}}
\end{gathered}
$$

where:

$B_{t}:$ Benefit from the perspective

$n$ : Project period cash flow is received

$r$ : Discounted rate

$\mathrm{CF}_{\mathrm{t}}$ : Net after-tax cash inflow-outflows during a period $\mathrm{t}$

\section{Results and discussion}

\subsection{Solar energy production}

Table 2 shows the energy production (MWh year ${ }^{-1}$ ) in a solar PV power plant depending on the equivalent hours per year (obtained by subtracting the system losses) and the installed power (MW). A typical solar PV power plant in Spain, with a power of $200 \mathrm{MW}$ and 1,600 effective hours of operation, could reach up to $320 \mathrm{GWh}$ year $^{-1}$.

Table 2. Solar energy production (MWh year ${ }^{-1}$ )

\begin{tabular}{c|cccc}
\hline $\begin{array}{c}\text { Equivalent } \\
\text { hours } \\
\text { [h year }^{-1} \text { ] }\end{array}$ & 100 & 200 & 300 & 400 \\
\cline { 2 - 5 } & 80,000 & 160,000 & 240,000 & 320,000 \\
800 & 100,000 & 200,000 & 300,000 & 400,000 \\
1,000 & 120,000 & 240,000 & 360,000 & 480,000 \\
1,200 & 140,000 & 280,000 & 420,000 & 560,000
\end{tabular}

\begin{tabular}{c|llll}
$\mathbf{1 , 6 0 0}$ & $\mathbf{1 6 0 , 0 0 0}$ & $\mathbf{3 2 0 , 0 0 0}$ & $\mathbf{4 8 0 , 0 0 0}$ & $\mathbf{6 4 0 , 0 0 0}$ \\
1,800 & 180,000 & 360,000 & 540,000 & 720,000 \\
\hline
\end{tabular}

Fig. 4 shows the energy production in $\mathrm{GWh}$ year ${ }^{-1}$ for solar PV power plants with 100, 200, 300 and $400 \mathrm{MW}$ of output power, considering 1,600 equivalent hours per year (typical value in the south of Spain) and a PV panel degradation of $0.5 \%$ year $^{-1}$. In the year 25 , a reduction of income of $12.5 \%$ is produced due to this issue.

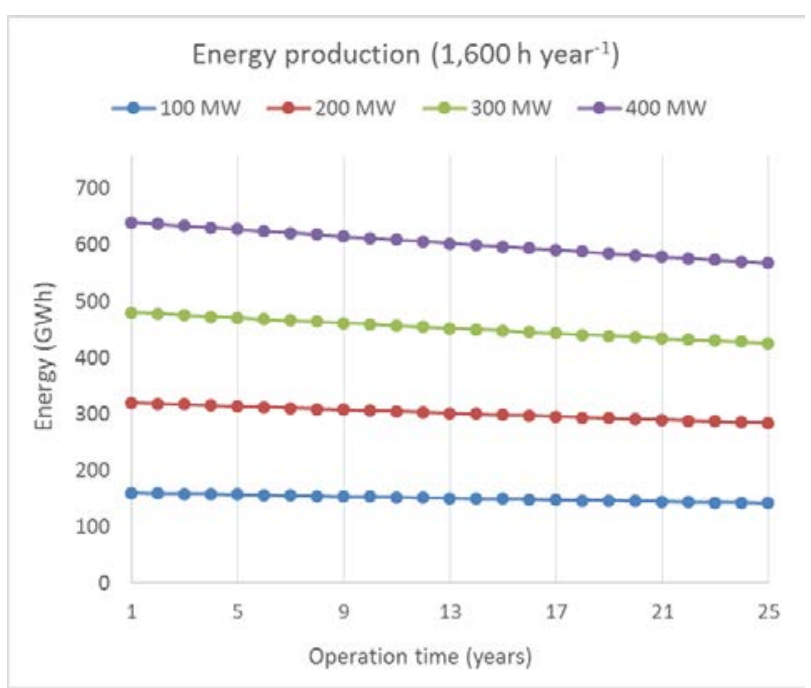

Fig. 4. Energy production $\left(\mathrm{GWh}\right.$ year $\left.^{-1}\right)$ considering $1,600 \mathrm{~h}$ year $^{-1}$ and a degradation of $0.5 \%$ year $^{-1}$.

\subsection{Investment and $0 \& M$ costs and land-take requirements}

Fig. 5 shows the summary of investment cost of a solar PV power plant with $100 \mathrm{MW}$ of output power. The main cost is supply and installation of the PV panel, with a $37.9 \%$ of the total cost.

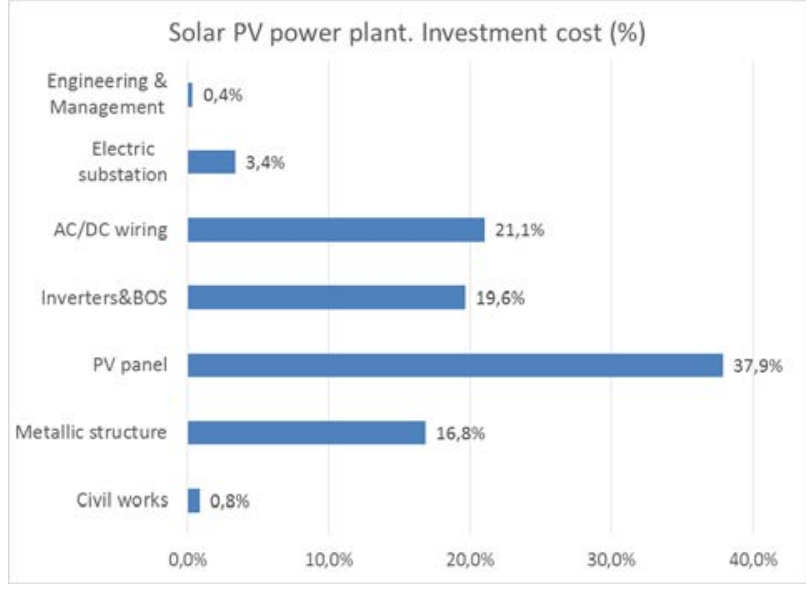

Fig. 5. Investment cost of a PV power plant with $100 \mathrm{MW}$ of power. Summary of cost items (\%)

Table 3 shows the investment cost, Operation and Maintenance (O\&M) costs and land-take requirements for solar PV power plants for output power between 100$400 \mathrm{MW}$. A power typical power plant with a power of 200 MW has an investment cost of 141.05 M€ and requires more than 190 ha of land. The land is usually 
rented during the period of operation of the PV power plant (25 years). A cost of $1,500 € \mathrm{ha}^{-1}$ year $^{-1}$ has been considered.

Table 3. Investment and O\&M costs and land-take requirements (ha)

\begin{tabular}{cccc}
\hline $\begin{array}{c}\text { Output } \\
\text { power (MW) }\end{array}$ & $\begin{array}{c}\text { CAPEX } \\
(\mathrm{M} €)\end{array}$ & $\begin{array}{c}\text { Land-take } \\
(\text { ha })\end{array}$ & $\begin{array}{c}\text { O\&M } \\
\left(\mathrm{M} \text { year }^{-1}\right)\end{array}$ \\
\hline 100 & 70.80 & 190.00 & 0.49 \\
200 & 141.05 & 380.00 & 0.87 \\
300 & 210.44 & 570.00 & 1.26 \\
400 & 276.05 & 760.00 & 1.64 \\
\hline
\end{tabular}

\subsection{Profitability analysis}

In this section, the results obtained in the economic model are shown. Table 4 shows the main parameters that have been considered in the economic model.

Table 4. Economic model parameters

\begin{tabular}{cc}
\hline Economic model parameters & \\
\hline Daily market price $\left(€ \mathrm{MWh}^{-1}\right)$ & $50-60$ \\
Operation time (years) & 25 \\
Equity (\%) & $20 \%$ \\
Debt (\%) & $80 \%$ \\
Loan interest rate (\%) & $3 \%$ \\
Loan term (years) & 15 \\
Depreciation (years) & 25 \\
Anual CPI (\%) & $2.0 \%$ \\
\hline
\end{tabular}

Fig. 6 shows the profitability analysis, NPV and IRR, for a PV power plant with a power of $100 \mathrm{MW}$ and a daily price in the electricity market of $50 € \mathrm{MWh}^{-1}$. In a typical PV power plant in the South of Spain, with an average of $1,600 \mathrm{~h}$ year $^{-1}$, NPV is $17.4 \mathrm{M} €$ and IRR reaches $6.91 \%$.

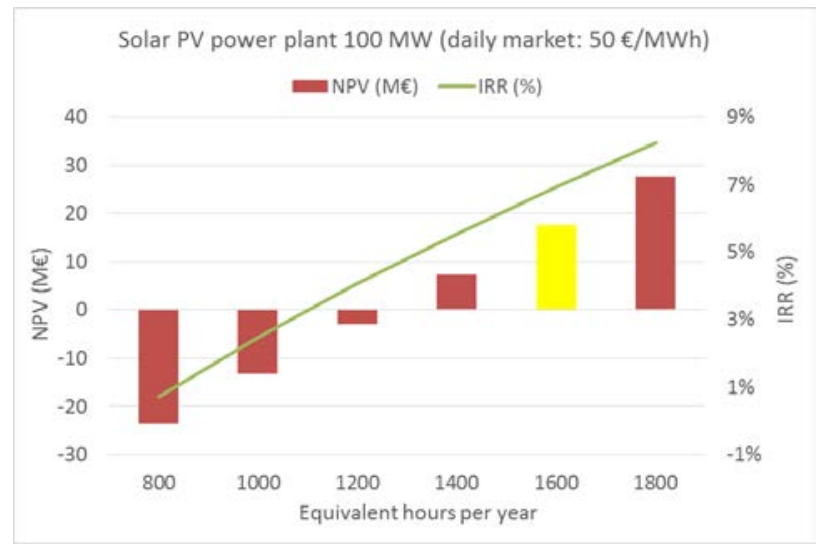

Fig. 6. Profitability analysis. PV power plant with $100 \mathrm{MW}$ of power and daily market price of $50 € \mathrm{MWh}^{-1}$.

Fig. 7 shows NPV and IRR for a PV power plant with a power of $100 \mathrm{MW}$ and a daily price in the electricity market of $60 € \mathrm{MWh}^{-1}$. In this scenario, NPV increases to $34 \mathrm{M} €$ and IRR increases to $9.01 \%$.

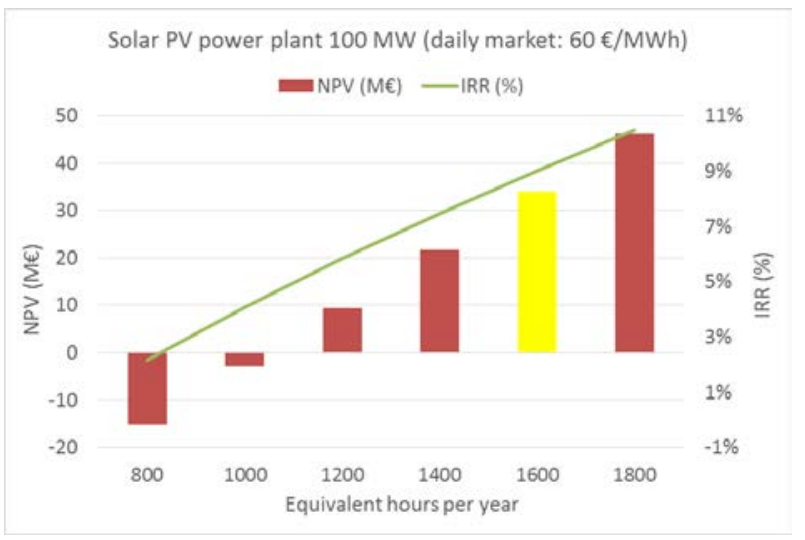

Fig. 7. Profitability analysis. PV power plant with $100 \mathrm{MW}$ of power and daily market price of $60 € \mathrm{MWh}^{-1}$.

Finally, Fig. 8 shows NPV and IRR values for a solar PV power plant with $400 \mathrm{MW}$ of power and a daily price in the electricity market of $60 € \mathrm{MWh}^{-1}$. In this scenario, NPV reaches $147 \mathrm{M} €$ and IRR is $9.49 \%$ for $1,600 \mathrm{~h}^{\text {year }}$ 1 .

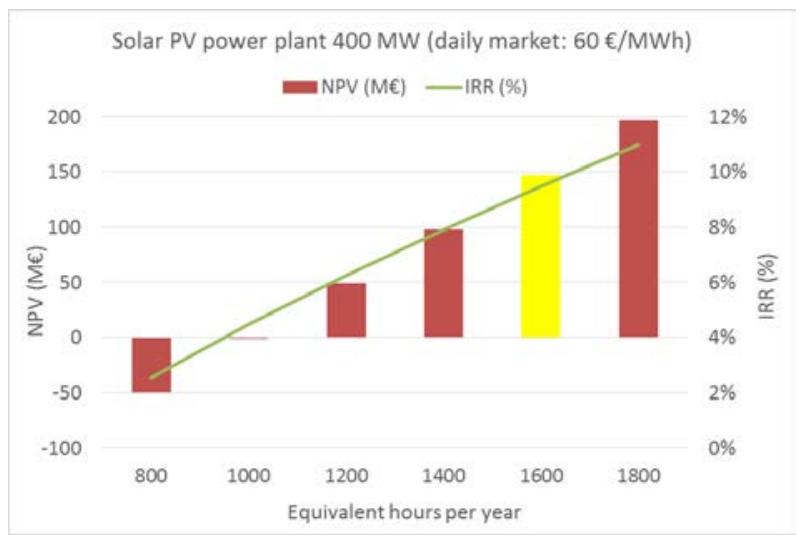

Fig. 8. Profitability analysis. PV power plant with $400 \mathrm{MW}$ of power and daily market price of $60 € \mathrm{MWh}^{-1}$.

\section{Conclusions}

Spain offers optimal conditions for the installation of solar PV power plants. The average solar irradiation in Spain is $1,600 \mathrm{kWh} \mathrm{m}^{-2}$. In this paper, the economic feasibility of large-scale solar PV power plants has been studied. PV power plants with power between 100-400 MW, with a number of equivalent hours between 800 $1,600 \mathrm{~h}^{-1} \mathrm{r}^{-1}$ have been considered.

The economic feasibility depends on the number of equivalent hours per year and the daily price in the electricity market. The results obtained show that the economic viability of these plants is reached for a number of hours exceeding $1,400 \mathrm{~h}_{\text {year }}{ }^{-1}$, fundamentally in PV power plants with powers below $200 \mathrm{MW}$. In the north of Spain, with a number of equivalent hours less than $1,200 \mathrm{~h}$ year $^{-1}$, there is no profitability for the current investment cost. 
In the south of Spain, with an average of $1,600 \mathrm{~h}$ year $^{-1}$, the profitability increases, reaching a NPV of 147 $\mathrm{M} €$ and an IRR of $9.49 \%$ for a solar PV plant of 400 MW of power and a daily price in the electricity market of $60 € \mathrm{MWh}^{-1}$. If the power of the plant is lower, the profitability is reduced, mainly because the O\&M costs are higher for each MWh produced.

\section{References}

1. International Energy Agency (IEA). Key world energy trends, except from: renewables information.

2. Menendez J, Loredo J, Fernandez-Oro J, Galdo M. Underground pumped-storage hydro power plants with mine water in abandoned coal mines. In: Proceedings of the IMWA 13th International Congress, (2017); pp. 6-13.

3. Menendez J, Loredo J, Fernandez-Oro JM, Galdo M. Energy storage in underground coal mines in NW Spain: Assessment of an underground lower water reservoir and preliminary energy balance. Renew. Energy (2019); 134:1381-1391. https://doi.org/10.1016/j.renene.2018.09.042

4. Menendez J, Ordóñez A, Álvarez R, Loredo J. Energy from closed mines: Underground energy storage and geothermal applications. Renew Sustainable Energy Rev (2019);108:498-512. https://doi.org/10.1016/j.rser.2019.04.007.

5. Menendez J, Loredo J. Use of closured open pit and underground coal mines for energy generation: Application to the Asturias Central Coal Basin
(Spain). E3S Web of Conferences (2019); 80: 01005. https://doi.org/10.1051/e3sconf/20198001005

6. Menendez J, Fernandez-Oro JM, Galdo M, Loredo J. Pumped-storage hydropower plants with underground reservoir: Influence of air pressure on the efficiency of the Francis turbine and energy production. Renew. Energy (2019); 143:1427-1438. https://doi.org/10.1016/j.renene.2019.05.099

7. Pablo-Romero $M$, Sánchez Braza A, Pérez M. Incentives to promote solar thermal energy in Spain. Renew Sustain Energy Rev (2013);22:198-208 http:// dx.doi.org/10.1016/j.rser.2013.01.034.

8. Huld T, Müller R, Gambardella A. A new solar radiation database for estimating $\mathrm{PV}$ performance in Europe and Africa. Solar Energy (2012); 86: 1803 1815.

9. Montoya F, Aguilera MJ, Manzano-Agugliaro F. Renewable energy production in Spain: A review Renew Sustainable Energy Rev (2014);33:509-531.

10. Moreno F, Martínez-Val JM. Collateral effects of renewable energies deployment in Spain: impact on thermal power plants performance and management. Energy Policy (2011);39(10):6561-74.

11. Ruiz-Arias J, Terrados J, Pérez-Higueras P, PozoVázquez D, Almonacid G. Assessment of the renewable energies potential for intensive electricity production in the Province of Jaén ,Southern Spain. Renew Sustain Energy Rev (2012);16(5):2994-3001 http://dx.doi.org/10.1016/j.rser.2012.02.006. 